\title{
単純へルへスの血清疫学的研究
}

第 2 報 中和抗体の分布型ならびにこれる $\mathrm{CF}$ 抗体との関係

\section{Serological-epidemiological Studies of Herpes Simplex}

II. On the Frequency Distributions of Virus-neutralizing Antibody and on the Relations between the Virus-neutralizing and Complement-fixing Antibodies

\author{
札幌医科大学衞生学教室 (主任 金光正次教授) \\ 山口晋 吾 \\ Shingo Yamaguchi \\ Department of Hygiene Sapporo Medical College
}

(Director: Prof. M. Kanamitsu)

\begin{abstract}
まえがき
前報1で私は都市在住の各種年䊀集団について, 単純 ヘルペスウィルス（H S V) に対する補体結合抗体（C $\mathrm{F}$ 抗体）を集団的に測定し，年齢ならびに居住環境と $\mathrm{C}$ $\mathrm{F}$ 抗体の分布型との関係, 平均抗体価の推移, 掞よ心同一 集団に打ける C F 抗体の 1 年間の変動などを観察してき た。本報ではこれについでH S V に対する中和抗体を各 種の年齢集団について定量的に測定し, 年齢と抗体分布 の型の関係, 同一集団に打ける抗体の集団変動, 扝よび $\mathrm{CF}$ 抗体と中和抗体との関係などを観察し, 前報の成績 とを総合して, 単純へルペスの免疫生成機序に関して血 清疫学的な見地から考察しょうと試みた。
\end{abstract}

\section{実験材料および実験方法}

\section{1) 対象集団}

昭和 32 年11月加ら昭和33年 5 月に至る間に，札幌市内 の某小学校児童 $(7 \sim 10$ 歳) 57名, 同市内某病院看護婦 (20 29歳) 72名, 同市内抢よび小樽市在住の鉄道職員 （40～55歳）飞札幌市某養老院に収容されている老年者 (55７5歳) 56名の計 185名から採血した。な押, 抗体 の集団変動をみるために, 市内小学学童56名加 1 年間 の間隔で組血清をとつた。血清は $56^{\circ} \mathrm{C} 30$ 分加熱したのち $4{ }^{\circ} \mathrm{C}$ に保存された。

\section{2）使用ウイルス}

本実験に使用したウィルス注 1956 年国立予防衛生研究 所の吉野博士から分与を受けたH F 401株を, 当研究室 において HeLa 細胞に17代継代したものである。

\section{3) 組織培萎法}

中和抗体の則定はすべて HeLa 細胞を用いておこな つた。HeLa 細胞は伝研の遠藤博士から分与された牛血 清馿化株を使用し, 細胞の培盖法ならびに抗体測定術式 は金光ら”がポリオの研究に用いた方法に準じておてな つた。すなわち細胞の増殖用培養液としては次の処方を 用いた。
Hanks 液
$79.4 \%$
非㗢化牛血清
$20.0 \%$
Yeast extract(Difco)
$0.1 \%$
Lactalbumin hydrolysate (N.B.C.) $0.5 \%$

またウィルスを感染させたのちの細胞維持用として は，次の培養液を使用した。

$\begin{array}{lr}\text { Earle 液 } & 94.4 \% \\ \text { 非働化馬血清 } & 5.0 \% \\ \text { Yeast extract(Difco) } & 0.1 \% \\ \text { Lactalbumin hydrolysate(N.B.C.) } & 0.5 \%\end{array}$

HeLa 細胞は Scherer ら ${ }^{3}$ の方法に準じ Trypsin 処 理を扢てなつた細胞を $5 \sim 10$ 万/cc の割合に上述の增殖 用培養液に浮遊し, 各試験管に $1 \mathrm{cc}$ ずつ分注して, いず れも静置法により $37^{\circ} \mathrm{C}$ の睬卵器の中で培養した。

\section{4）血清中和抗体の測定法}

$56^{\circ} \mathrm{C} 30$ 分加熱非働化した被検血清を細胞維持用培養液 で 2 倍階段稀釈し，とれに HeLa 細胞で培養した HSV の培養液を，抢よそ 100 TCID $_{50}$ に稀釈したものを等量

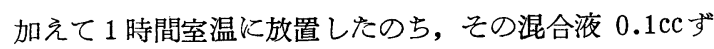
つを各々 3 本の HeLa 細胞培養管に接種し, ついでと 
第 1 図 都市在住の各年齡集団别単純へルペス中和抗体の分布 小学又童 $\left(\begin{array}{l}7 \sim 10 \ddagger) \\ N=57\end{array}\right.$

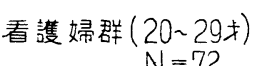

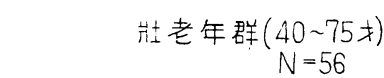
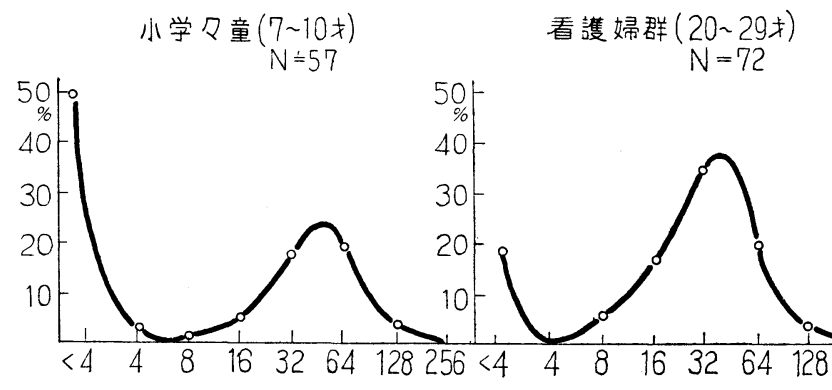

れに維持用培養液 $1 \mathrm{ml}$ を注加した。判定は培養後 6 〜 7 日目に抢こない, Reed and Muench の方法でその感 染価を測定した。中和抗体の価㤕 $100 \mathrm{TCID}_{50}$ のウィル スに対し $50 \%$ 中和を示す被検血清の初期稀釈培数 (initial dilution)をもつて表わした。な押, 細胞変性の基準 注H S V の感染化よつて生じる特異な巨細胞が，全視野 ๑30\%以上に西らわれた場合を陽性とした。

\section{実験成績}

\section{1) 各年竛集団におけるへルペス中和抗体の分布}

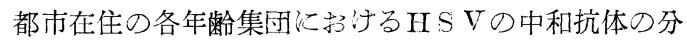
布状況を及るために, 札幌市の小学学童 ( $7 \sim 9$ 藏), 医 大看護婦集団 (20 29歳), および都市在住の40歳以上の 壮老年の 3 年齢集団について中和抗体を定量的に測定し た。第1図法その成績を示したものである。すなわち学 童群では $50 \%$ が抗体陰性で, 残りの大半は 32 64倍比集 積し定型的な 2 峰型の分布をなしている。しかも 4 〜 16 倍という中間值を示す者が少なく, Burnet ${ }^{4)}$ のいわる “all or none”の法則徒つた分布型を示す。看護婦 群でも同じく 2 峰型の分布を示すが，抗体陰性者は $20 \%$ に減少し,残りの大部分注 $16 \sim 64$ 倍に集積し,第 2 峰泣前 群に比し著しく高い。壮老年群では抗体陰性者はわずか 飞 $5 \%$ で, 残りの $95 \%$ は 8 128 倍の抗体保有し, 特 に32 64倍付近に強く集積する傾向があり，前 2 群とは 異なり単峰型の分布である。し亦し抗体分布のモードは 各年秢集団を通じ海とんど一定で32〜64倍の值を示して いる。また学童群・看護婦群・壮老年群の各中和抗体の 分布型は前報に示したそれぞれ就学前，10１9歳，30～ 39歳の各 C F抗体の分布型ときわめて類似しているとと は興味がある。

\section{2) 中和抗体と $\mathbf{C F}$ 抗体との関係}

都市在住の各年赖集団についてそれぞれ中和抗体と $\mathrm{C}$ $\mathrm{F}$ 抗体とを同時に測定し，両者の関係をみると第 2 四の ごとくなる。すなわち小学学童群においては C F 抗体陰

第 2 図 各年齢集団における $\mathrm{CF} ・$ 中和 両抗体の相互関係

都市小学々童 $(7 \sim 10 \succsim)$
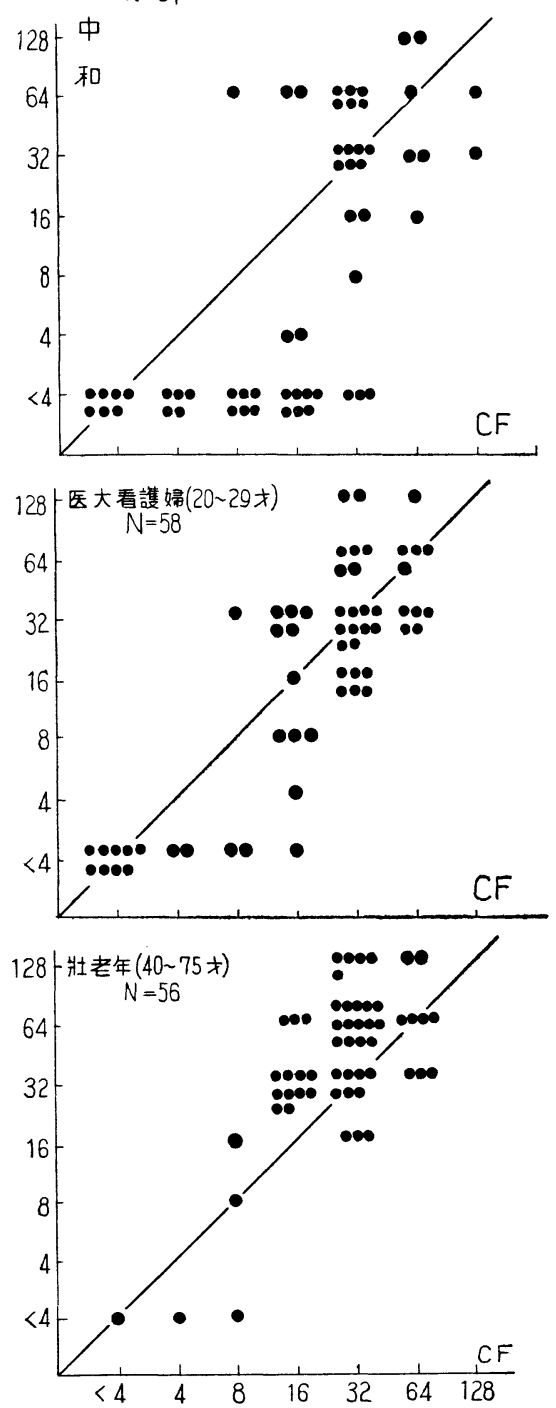
性者は中和抗体もまた認められない。また C F抗体を保 有する者でも42例中 21 例 (50\%) は中和抗体が陰性であ る。とれに対し 4 倍以上の中和抗体を保有する者はすべ て 8 倍以上の $\mathrm{C}$ F抗体を保有し, かつ両抗体の価注名 なり密接な順相関が認められる。とれと同様の関係は看 護婦集団に扮いても認められるが，40歳以上の壮老年者 では両抗体ともに陰性の者がきわめて少なく，両抗体と も16〜64倍の価を示す者が大多数なために，両者の間に はかなり緊密な順相関関係がある。以上の成績から各年 齢集団を通じて共通なととは，C F 抗体を欠く者は中和 抗体もまた認められないとと，また8倍以上の中和抗体 を保有する者についてい，両抗体間に緊密な順相関関係 が認められることである。しかし学童群に执いては16〜 32倍という比較的高い C F 抗体価を示す者でも，かなり の数に中和抗体を欠き, 両者間认は相関関係が認められ なかつた。な技, 中和抗体陰性者群に対し, 感染ウィル スの量を40〜80 TCID 50 に減じて抗体を再測定したが, 抗体㳖然として検出しえなかつた。

\section{3）同一集団における中和抗体の変動状況}

同一の集団に扝いて，一定の時日を経過したのち，H S V V対する中和抗体がぞのる.うに変動するかを観察し た。札幌市内某小学学童 $(1 \sim 4$ 年生) 56 名を選び, 1 年 間の間隔で採血して得た組血清について中和抗体を定量

\section{第 3 図都市小学学童 (7 10 歳) の 1 年後 における中和抗体の変動 $\mathrm{N}=56$}

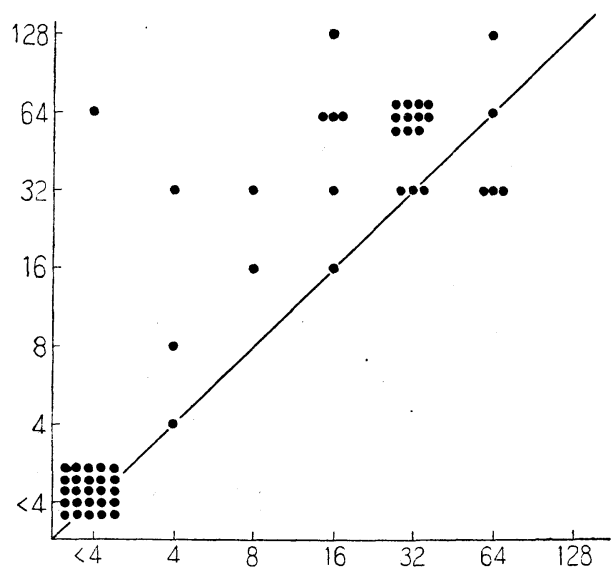

的に測定し，抗体の集団変動状況をみると第 3 図のてと くである。すなわち初めに 4 倍以上の抗体を保有してい た者では，大部分において抗体の上昇を示している。と ころが初めに64倍という高い抗体を保有していた者の中 には, 逆に抗体価が低下した者も数例認められた。しか
し初めに抗体を欠如した者は，1年後においてもほとん ぞ変化がなく，わずかに 1 例の及 64 倍末で上昇したもの があつた。前報”で観察したどとく C F 抗体に扎いては 初期に抗体を欠く者に抗体上昇した者が多いととと比べ きわめて対照的である。すなわち中和抗体が 1 年後にお いても依然陰性でありながら，C F 抗体の明らかな上昇 を示した者も少なくない。しかしいつたん出現した中和 抗体は 1 年後に揖いて再び消失じ者は 1 例もない。

\section{4) 中和抗体と CF 抗体の変動の関係}

前述のごとく，同じ個体について同時期に測定した中 和抗体と C F 抗体の価は必ずしも比例しない。よつて次 に同じ個体に㧤ける 1 年間の両抗体の上昇执よこ低下に ぞのような関係があるかを観察した。まず初期に中和抗 体が 4 倍以上の価を保有していた者について, その後 1 年間における両抗体の変動を及ると第 1 表 (a)のごとく である。すなわちとの間に中和抗体が 2 倍以上上昇した

抗体陽性者における CF・中和両抗体の 変動の関係 (小学学童)

第 1 表 (a)

第 1 表 $(\mathbf{b})$

\begin{tabular}{|c|c|c|c|c|c|}
\hline & CF抗体 & $\begin{array}{l}2 \text { 倍以上 } \\
\text { の变動 }\end{array}$ & & 中和抗体 & $\begin{array}{l}2 \text { 倍以上 } \\
\text { の变動 }\end{array}$ \\
\hline \multirow{3}{*}{$\begin{array}{c}\text { 中和抗 } \\
\text { 体上昇 } \\
\text { 群 } \\
{ }_{19}\end{array}$} & 上 昇 & 9 & \multirow{3}{*}{$\begin{array}{c}\mathrm{CF} \text { 抗体 } \\
\text { 上昇群 } \\
13\end{array}$} & 上 昇 & 9 \\
\hline & 不 変 & 8 & & 不 変 & 3 \\
\hline & 低 下 & 2 & & 低 下 & 1 \\
\hline \multirow{2}{*}{ 不変群 } & 上 昇 & 2 & \multirow{3}{*}{$\begin{array}{c}\text { 不変群 } \\
15\end{array}$} & 上 昇 & 8 \\
\hline & 不 変 & 2 & & 不 変 & 7 \\
\hline 4 & 低 下 & 0 & & 低 下 & 0 \\
\hline 低下群 & 上 昇 & 1 & 低下群 & 上 昇 & 3 \\
\hline 1 & 不 変 & 0 & 5 & 不 変 & 2 \\
\hline
\end{tabular}

19名のうち, CF 抗体が同様に 2 倍以上の上昇を示した者 が 9 名,不変 8 名, 2 倍以上低下した者が 2 名である。ま た中和抗体に変動の及られなかつた 4 名のうち, 2 名に 扮いてC F抗体の明らかな上昇が認められる。またての 間に中和抗体の低下した者心 1 名のみであるが, C F 抗 体は反対に上昇している。すなわち C F抗体の変動が中 和抗体のそれと同じ傾向を示した者は約半数にすきな い。第 1 表(b)は初期に 4 倍以上の C F抗体を保有してい る者について, その後 1 年間の変動傾向を基準として中 和抗体の変動を観察した成績である。表にみるょうに， $\mathrm{CF}$ 抗体が 2 倍以上上昇した 13 名中 9 名はCF抗体も同様 に上昇しており,両者の変動傾向はかなりよく一致する。 しかし C F 抗体不変群掞よび低下群では, 中和抗体がこ 
れと同じ変動傾向を示す者はいずれも半数にすぎず，と の場合にも両抗体の変動はあまり緊密とはいえない。

第 2 表 (a)は初期に中和抗体が証明されず,その後も陰 性であつた20名について，1 年間に扔ける $\mathrm{C} \mathrm{F}$ 抗体の変 動状況を観祭した成績である。との場合にも，C F抗体 に変動のなかつ心者は 12 名にすぎず，他の 6 名では明ら

\section{抗体陰性者における CF・中和両抗体の 変動の関係 第 2 表 $(\mathbf{a})$ 第 2 表 $(\mathbf{b})$}

\begin{tabular}{|c|c|c|c|c|c|}
\hline & $\mathrm{CF}$ 抗体 & $\begin{array}{l}2 \text { 倍以上 } \\
\text { の変動 }\end{array}$ & & 中和抗体 & $\begin{array}{l}2 \text { 㜔以上 } \\
\text { の変動 }\end{array}$ \\
\hline \multirow{3}{*}{$\begin{array}{l}\text { 中和抗 } \\
\text { 体不变 } \\
\text { 群 } \\
\quad 20\end{array}$} & 上 昇 & 6 & CF抗体 & 上 昇 & 0 \\
\hline & 不 変 & 12 & 上昇群 & 不 変 & 5 \\
\hline & 低 下 & 2 & 5 & 低 下 & 0 \\
\hline & & & 不変群 & 上 昇 & 0 \\
\hline & & & & 不 変 & 7 \\
\hline & & & & 低 下 & 0 \\
\hline
\end{tabular}

かな上昇が，また 2 名には低下を認めた。な招初期に中 和抗体陰性で，之の後に本抗体が上昇した者は 1 名の及 で,そのCF抗体注低下を示した。第 2 表(b) は C F 抗体 陰性者について，その後の本抗体と中和抗体の変動傾向 を比較した成績である。表に明らかなようにC F 抗体の 上昇に伴なつて中和抗体も上昇した者社 1 名もなく，両 抗体の変動はまつたく平行しない。しかし C F 抗体に変 化つなかつた 7 名では全例が中和抗体も変動せず，この 場合炕きわめてょく一致している。以上の成績から中 和・ C F 両抗体の変動の相互関係法, 初期に打ける各抗 体の保有状況抢よび比較の際の条件倸よつて異なりきわ めて複雑である。しかし総括的にみて両抗体の変動傾向 はあまり緊密なものでないととがうかがわれる。

\section{考按}

単純ヘルペスのどとく, 顕性患者に比べて不顕性感染 者が著しく多く, かつ大きな流行をみるととのきわめて 稀な疾患の疫学を研究するには, 臨床的観察は勿論であ るが, 血清疫学的な見地から本ウィルスに対する血清抗 体の分布を究明し，との方面からの検討が重要なとと牥 いうまでもない。過去に抢けるH S V に対する中和抗 体の測定には種々の実験動物または睬化鵎卵が使われ

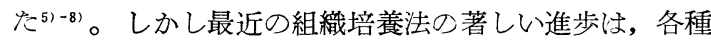
のウィルス病の研究に飛羅的な進歩をもたらしな。すな わち1953年 Scherer ら ${ }^{3}$ はポリオウィルスが HeLa 細 胞汇增殖すると同時に特有な細胞病理学的変化を与える

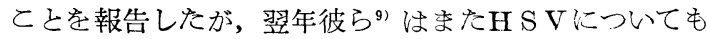

同様な成績安報告した。H S V は HeLa 細胞牧かりで なく, マウスの fibroblastic cell(L strain $)^{10)}$ や, 人胎児 の肺組織 ${ }^{111}$ ，鬼の腎細胞 ${ }^{12)}$ などにも増殖し，かつとれら の細胞の破壊変性を起すととが知られている。本報で注 HeLa 細胞を用いて中和抗体を定量的に測定した。細胞 変性は Gray ら ${ }^{13)}$ の成績に基づき巨細胞の出現の有無 をもつて判定基準とした。HeLa 細胞に継代した初期つ 頃にはこの巨細胞はまつたく認められなかつたが, 継代 を重ねるにしたがつて出現するようになつた。

種々の条件下に扮けるHSVの保存については二，三

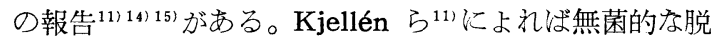
脂粉乳で 2 倍に稀䣋し, 密封したアンプルに入れアイス ボックスに貯蔵されたH S Vは少なくとも 3 カ月間はそ の感染価を保つという。本報つ中和試験に用いたウイル スはー $15^{\circ} \mathrm{C}$ に保存したが, この場合, ウィルスの感染価 が時日の経過とともにどのように変化するか子みると, 貯蔵前の感染価がー6.4 であつたものが, 8 日目には一 5.5 に低下し，22日目にはさらに一4.6に低下した。し かしその後 1 カ月以上は同じ值を維持した。したがつて Kjellén らのごとき方法を用いてょり低い温度で保存卞 るならば，H S V は相当長期間その感染価を維持するも のと思う。

人血清中に打ける中和抗体の分布については多くの研 究報告(5)-8) 16)-20) があるが，その㴽とんどは種々の実験 動物态たは睬化鴊卵を用いたものであつて, 組織培養法 によつて抗体を定量的に測定した報告はきわめて少な い。Anderson ら ${ }^{16)}$ によれば母親から得た抗体怯生後 3 力月から15力月の間汇消失し，生後 7 力月〜 14 力月汇至 れば原とんどが本ウィルスに対する抗体を失うという。 また Weyer ${ }^{7)}$ によれば $5 \sim 10$ 歳の中和抗体保有率は 38 〜 50\%，20〜30歳は70〜90\%であり，Buddingh ら ${ }^{20}$ は 成人の抗体保有率は90 96\%で，乙れらの成績㹥本報の 成績とよく一致する。最近, 館野ら ${ }^{21}$ 沈人胎児組織培養 法を用いて中和抗体を測定したが，その保有率结 10 藏以 下 $20 \% ， 20$ 30歳80\%で，HeLa 細胞による本報の成績 と近似している。

抗体分布の型について, Burnet ら"初め人血清中

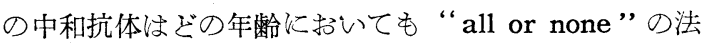
則に従うと提唱した。すなわち人間は本抗体をまつたく もたないか，あるい惊高い值を保有する 2 群に登れると いう。との説については賛成する者 ${ }^{17719)}$ と，乙れに異議 をとなえる者 ${ }^{182}$ 20122) とがあるが, 本報の成績仙よれば

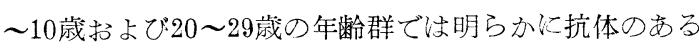
者とない者が判然とし, 中間值を示すものが少なく, “all 
or none” の法則に従つた抗体分布を示している。しか し40歳以上では抗体陰性者が潘とんごなく単峰型の分布 である。すなわち Burnet の法則は若年阾集団には適 用されるが，40歳以上の成人群ではまつたく通用しない ことを知つた。これは $\operatorname{Rose}^{23)}$ が指摘しているょうに, Burnet らが用いた抗体測定法の欠陥のほか, 集団の居 住環境・年秢的因子なども影響するものと思う。

H S VK対する C F抗体と中和抗体との関係について は, 両者は密接に関連するという者 ${ }^{171}$ 192 24) $^{2}$, 両者間の 完全な相関関係を否定する者 ${ }^{12225)}$ とがある。後者注中和 指数の高いものは C F 抗体価も高く, 両者の間に関連が あるが，中和指数のきわめて低いものは $\mathrm{CF}$ 抗体がまつ たく認められないという。本報では 7 １0歳，20２9歳 扣よび40歳以上の 3 群について両抗体の関係を観察し た。その結果どの集団に执いても， C F 抗体のないもの は中和抗体もまたまつたく認められなかつたが，その逆 壮必ずしも成立しないととを知つた。しかし 8 倍以上の 中和抗体をもつている者では, 両抗体間に明らかな順相 関関係を認めた。ただし 4 〜2倍の C F抗体をもつてい

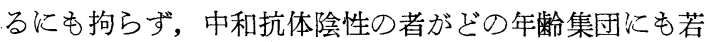
干例認められたが, 特に学童群ではこの関係が顕著であ つた。

このととはまた両抗体の 1 年間の変動の相互関係にお いても認められた。すなわ耐抗体の変動初期に打い ていずれかの抗体を保有しているか否かによつて著しく 影響され，また変動を比較する際の基準となる抗体の種 類によつても異なり, その相互関係はきわめて複雑であ る。現在, 中和・C F 両抗体の出現消長の機序については 多くの説 19) 20126) 27)があるが，本報の成績によれば少なく とも両抗体の出現（測定可能な価までの上昇）に注，氻 なりの時間的差異があるょうに思られる。しかし，とれ が単に中和抗体の出現が C F 抗体より遅いという時間的 ズレであるか, その出現機序に本質的な差異があるのか は不明である。本報で注目されたもう 1 つの点は, 中和 抗体の分布の第 2 峰のモードが集団のいかんに拘らず㴗 とんど一定の值を示したととで，とれは前報に述べた C F抗体の分布の性状とも類似している。すなす策純へ ルペスでは中和・C F 両抗体ともに特有の分布の性状を 有するととはきわめて注目すべきことで，乙のことは $\mathrm{H}$ $\mathrm{S} V$ の存在様式, 本ウィルスによる感染発病ならびに免 疫産生の機序を研究するうえに新たな端緒をなす事実と 思う。

\section{結 論}

1）都市に在住する各年齢集団について，H S V に対 する中和抗体を定量的に測定し, 本抗体の分布型, 1 年 間に招けるその集団的変動ならびに中和抗体と C F 抗体 との静的扝よび動的相に㧍ける相互関係を観察した。

2）小学学童群について中和抗体の 1 年間の変動を観 察した結果，抗体陰性者は汪とんぞ本抗体の上昇を及な かつたが，抗体陽性者では夭部分が上昇を示した。

3）同じ時期に測定したC F と中和両抗体の関係を各 年齢集団について観察し, 中和抗体陽性者については両 抗体の順相関を認めたが, 中和抗体陰性者では両者の間 にかかる関係は認められなかつた。

4）小学学童について 1 年間における中和・ C F 両抗 体の変動の相互関係学観察した結果, 両者の变動傾向は 必ずしも一致しないととを知つた。

5）前報抢よび本報の成績から，単純へルペスの免疫 成立機序を考察した。

擱筆飞当り，終始御懇篤な御指導・御援助ならびに御 校閲を賜わつた金光教授に深謝するとともに，血清採取 に御援助・御協力をいただいた北光小学校教官各位, 札 幌医大看護婦各位，札幌 - 小樽各機関区職員，札幌市養 老院院長，扣よび被検者各位に扣礼申しあげ，また教室

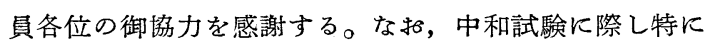
御助力をいただいた教室の河原林・橋本両先生に感謝致 します。

本研究の要旨は第 12 回日本公衆衞生学会, ならびと 第 6 回日本ウィルス学会の席上に揦いて発表した。

\section{文献}

1）山口：日本衛生学雑誌 $13,842,1959$.

2) 金光他: 日本衞生学雑誌 $13,406,1958$.

3) Scherer, W. F. et al. : J. Exp. Med. 97,695, 1953.

4) Burnet, F. M. \& Williams, S. W. : Med. J. Austral. 1, 637, 1939.

5) Zinsser, H. \& Tang, F.: J. Immunol. 17, 343, 1929.

6) Andrewes, G. H. \& Carmichael, E. A. : Lancet 1, 857, 1930.

7) Weyer, E. R.: Proc. Soc. Exp. Biol. \& Med. 30, 309, 1932.

8) Burnet, F. M. \& Lush, D.: Lancet 1, 629, 1939.

9) Scherer, W. F. \& Syverton, J. T.: Am. J. Path. 30, 1057, 1954.

10) Scherer, W. F.: Am. J. Path. 29, 113, 1953 
11) Kjellén, L. \& Svedmyr, A.: Arch. ges. Virusfor. 5, 373, 1954.

12) José Sosa-Martinetz et al. : J. Bact. 70, 391, 1955.

13) Gray, A. et al. : Arch. ges. Virusfor. 8, 59, 1958.

14) Speck, R. S. et al. : J. Bact. 61, 253, 1951.

15) Allen, E. G. et al. : J. Bact. 63, 369, 1952.

16) Anderson, S. G. \& Hamilton, J. : Med. J. Austral. 1, 308, 1949.

17) Hayward, M. E. : Lancet 1, 856, 1950.

18) Jawetz, E. \& Coleman, V. R. : J. Immunol. 68, 645, 1952.

19) Dudgeon, J. A. : J. Clin. Path. 3, 239, 1950.
20) Buddingh, G. H. et al. : Pediatrics 11,595, 1953.

21）館野他：東京医事新誌 $75,11,1958$,

22) Kilbourne, E. D. \& Harsfall, F. L. : Arch. Int. Med. 88, 495, 1951.

23) Rose, H. M. : J. Immunol. 68, 687, 1952.

24) Dascomb, H. E. et al. : J. Lab. Clin. Med. 46, 1, 1955.

25) Gajdusek, D. C. : J. Am. Med. Ass. 149, 235, 1952.

26) Jawetz, E. : Fed. Proc. 11, 472, 1952.

27) Brain, R. T. : Brit. Med. J. 2, 1064, 1937.

(受付 : 1958 年 11 月 26 日，特別掲載） 